\title{
EKSAGREGUOTA PLACENTOS VIETA: KLINIKINIS ATVEJIS
}

\author{
Dovilè Smetonienè ${ }^{1}$, Jelena Volochovič ${ }^{1,2}$ \\ ${ }^{1}$ Vilniaus universiteto Medicinos fakulteto Akušerijos ir ginekologijos klinika, \\ ${ }^{2}$ Vilniaus universiteto ligoninès Santaros kliniku Akušerijos ir ginekologijos centras
}

Raktažodžiai: eksagreguota placentos vieta, tarpinis trofoblastas, kraujavimas nëštumo metu.

\begin{abstract}
Santrauka
Eksagreguota placentos vieta - nepiktybinè patologija, kuriai būdinga tarpinio trofoblasto išplitimas endomiometriume normalioje placentos prisitvirtinimo vietoje. Dažniausiai diagnozuojama atsitiktinai tiriant savaiminių persileidimų ar nėštumų nutraukimų medžiagą. Apie klinikinę eigą žinoma mažai, iki šiol anglų kalba aprašyta vos keliolika šios patologijos atvejų. Tarp klinikinių pasireiškimų aprašoma negausus pasikartojantis tepimas kraujingomis išskyromis ar stiprus kraujavimas iš gimdos nèštumo metu, gimdos atonija ir gausus kraujavimas po gimdymo ar net pažeistos gimdos sienelès perforacija. Eksagreguotą placentos vietą būtina diferencijuoti nuo kitų gerybinių ir ypač paribinių ar piktybinių susirgimų, tokių kaip placentos vietos trofoblastinis navikas, epitelioidinis trofoblastinis navikas ir choriokarcinoma, kuriems reikalingi agresyvūs gydymo protokolai. Darbo tikslas: pristatyti šios retos, mažai klinicistams žinomos patologijos klinikini atvejị ir išnagrinèti mokslinès literatūros duomenis. Metodas ir tyrimo medžiaga: pristatome retą egsagreguotos placentos vietos, nustatytos 18 savaičių néščiai moteriai, klinikini atvejį. Moteris atvyko dèl pasikartojančio gausaus gyvybei pavojingo kraujavimo iš genitalijų. Bendro aptarimo metu nutarta toliau něštumo nebetęsti. Operacijos metu įtarus patologiškai prisitvirtinusią placentą, atlikta totalinẻ histerektomija be gimdos priedų pašalinimo. Histologinio tyrimo išvada - eksagreguota placentos vieta.

Išvados: šis klinikinis atvejis rodo, kad esant kraujavimui iš gimdos nèštumo metu ir neradus kitos kraujavimo priežasties, būtina pagalvoti apie eksagreguotą placentos vietą. Šią nepiktybinę patologiją būtina diferencijuoti nuo kitų trofoblastinių ligų.
\end{abstract}

Ivadas

Eksagreguota placentos vieta (EPV) - tai nepiktybinis trofoblastinis pažeidimas, kuomet negaurelinio tarpinio trofoblasto ląstelès plačiai infiltruoja endometriumą ir miometriumą, kraujagyslių sieneles normalioje placentos prisitvirtinimo vietoje [1]. Dažniausiai ši patologija diagnozuojama tiriant savaiminių persileidimų ar něštumų nutraukimų medžiagą [6]. Retai sukelia kraujavimą nèštumo metu, gimdos atoniją ir gausų kraujavimą po gimdymo ar net pažeistos gimdos sienelès perforaciją [2,4]. Eksagreguota placentos vieta gali lydèti normalų nèštumą, ektopinị néštumą, persileidimą, pūslinę išvisą [3]. EPV nesiejama su padidèjusia persistuojančios trofoblastinès ligos rizika, joks specifinis gydymas nereikalingas. Tačiau būtina diferencijuoti nuo kitų trofoblastinių pažeidimų, ypač paribinio piktybiškumo ir piktybinių, kuriems reikalingas agresyvus gydymas[1].

Mūsų darbo tikslas: pristatyti klinikinį atvejị ir išnagrinèti mokslinès literatūros duomenis apie šią retą akušerinę patologiją.

\section{Klinikinis atvejis}

Něščioji, 36 metų, greitosios medicinos pagalbos automobiliu atvežta iš Respublikinès Panevėžio ligoninès i Vilniaus universiteto ligoninès Santaros klinikų (VULSK) Akušerijos ir ginekologijos centrą dèl kraujavimo iš genitalijų. Nëštumas dešimtas, 18 savaičių. Šis nèštumas neplanuotas, paskutinių mėnesinių neatsimena, nėštumo laikas skaičiuojamas pagal pirmajji ultragarsini tyrimą 17 néštumo savaitę. Praeityje vienas priešlaikinis savaiminis gimdymas (1999 metais) ir vienas savalaikis savaiminis gimdymas (2000 metais), septyni néštumo nutraukimai.

Šis kraujavimo epizodas antras. Pirmą kartą kraujavo prieš 2 savaites, gydyta Panevėžio ligoninejje ir VULSK Něštumo patologijos skyriuje. Itariant gimdos kaklelio věži atlikta biopsija. Histologinis atsakymas: nespecifinis lètinis aktyvus cervicitas. Kraujavimui sustojus išrašyta ị namus. Pasikartojus gausiam kraujavimui (ligonès žodžiais apie vieną litrą) hospitalizuota ị Panevėžio ligoninę pakartotinai. 
Tamponuota makštis. Dėl ryškios mažakraujystès (Hb 61 g/l) atlikta dviejų vienetų eritrocitų masès transfuzija. Moteris pervežta ị tretinio lygio VULSK tolimesniam ištyrimui ir gydymui.

Atvykus skundèsi bendru silpnumu. Bendra būklè vidutine, hemodinamika stabili, AKS 128/75 mmHg, pulsas 82 kartai per minutę. Temperatūra $36,6^{\circ} \mathrm{C}$. Vaisiaus širdies tonai ritmiški, aiškūs, 130 kartų per minutę. Gimdos tonusas normalus. Makštyje setonas.

Ištraukus makšties tamponą aktyvaus kraujavimo nestebèta. Apžiūrint makšties sketikliais: makštyje negausios rusvos išskyros, gimdos kaklelis suformuotas, priekinès gimdos kaklelio lūpos kraujagyslių išsipletimas. Paimtas citologinis tyrimas ị skystą terpę - atipinių ląstelių nerasta.

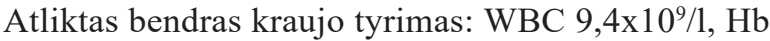
$82 \mathrm{~g} / 1$, PLT 118x10\%/1, CRB 3,4 g/l. Echoskopiškai stebèta žemai prisitvirtinusi placenta, gimdos apatinio segmento ir gimdos kaklelio venų varikozè. Pilvo magnetinio rezonanso tomografijos duomenimis, placenta prisitvirtinusi gimdos užpakalinëje sienoje, nedidelis vingiuotų kraujagyslių tinklas ties apatiniu placentos kraštu greta gimdos kaklelio kanalo vidinès angos bei gimdos kaklelio priekinèje dalyje su kraujagyslių prolabacija link kaklelio kanalo.

Stacionare gausus kraujavimas kartojosi. Dèl pasikartojančio, gyvybei pavojingo kraujavimo konsiliumo nutarta toliau nèštumo netęsti. Operacijos metu ịtarus patologiškai prisitvirtinusią placentą, atlikta totalinè histerektomija be gimdos priedų pašalinimo. Po operacijos moteris vieną parą gydyta RITS. Ketvirtą parą po operacijos patenkinamos būklès išrašyta ị namus.

Operacijos medžiaga išsiųsta histologiniam ištyrimui.

Makroskopiškai: miometriumas su fibrozès pluoštais, subserozinis miomos mazgas $1,4 \times 0,7 \times 0,4 \mathrm{~cm}$ ir intramuralinis miomos mazgas $1,5 \times 1 \times 0,6 \mathrm{~cm}$, placenta su centre prisitvirtinusia virkštele, vaisius be išorinių ir vidinių apsigimimo požymių.

Mikroskopiškai: miometriumą infiltruoja tarpinio trofoblasto ląstelès su gausia eozinofiliška citoplazma ir apvaliais branduoliais. Gausios daugiabranduolès ląstelès. Matomos hemoragijos, intravaskulinè tarpinio trofoblasto ląstelių invazija. Placentos choriono gaureliai vaskuliarizuoti ir edemiški, su tarpgaurelinemis fibrino sankaupomis. Uždegiminès infiltracijos nèra. Mitozinio aktyvumo ir nekrozès nestebèta.

Histologinio tyrimo išvada: eksagreguota placentos vieta. Gimdos kaklelio mucininès cistos. Gimdos lejomiomos. Placenta, atitinkanti gestacijos amžių.

\section{Diskusija}

Eksagreguota placentos vieta - tai nepiktybinis pažeidi- mas, kuriam būdinga negaurelinio tarpinio trofoblasto gausi infiltracija ị endometriumą, miometriumą ir kraujagyslių sieneles placentos prisitvirtinimo vietoje. Tipiškai ši patologija randama tiriant savaiminių persileidimų ar néštumo nutraukimų medžiagą. Rečiau aptinkama normaliai besivystančiame něštume ar po gimdymo.

Eksagreguotos placentos vietos ir normalios placentos vietos tarpinio trofoblasto ląsteliu imunofenotipinis profilis identiškas [4]. Tarpinio trofoblasto ląstelès svarbios néštumo palaikymui, pagrindinè jų funkcija yra pritvirtinti placentą prie motinos audinių [2]. Nèštumo pradžioje šios ląstelès infiltruoja atkrintančiąą plèvę, viršutinę dalị miometriumo, spiralines arterijas ir tai yra fiziologinis procesas, užtikrinantis motinos ir vaisiaus cirkuliaciją. Něštumui augant ši infiltracija pamažu regresuoja. Taigi, kai tarpinio trofoblasto ląstelès plačiai ir gausiai infiltruoja gimdos raumeninị sluoksnį, neregresuoja, ši būklè ir vadinama EPV [1].

Praeityje šiai patologijai apibrěžti buvo naudojamas kitas terminas - sincitinis endometritas. Tačiau tai nèra nei uždegiminis procesas, nei apsiriboja endometriumu, dauguma ląstelių nèra sincitinès, todèl Pasaulio sveikatos organizacija (PSO) ịvedè EPV terminą [1]. Eksagreguota placentos vieta gali lydėti normalų něštumą, ektopinį něštumą, persileidimą, pūslinę išvisą [3].

Dažniausiai EPV - tai histologinè diagnozè, aptinkama tiriant pirmojo trimestro persileidimų ar néštumo nutraukimų abrazinę medžiagą, randama 1,6 proc. atvejų. Pranešimų apie šios patologijos klinikinę eigą labai mažai. Takebayashi ir kt. apžvelgè vienolika klinikinių atvejų, publikuotų per 24 metus - EPV diagnozuota pirmojo trimestro persileidimo, néštumo nutraukimo, kaklelinio nèštumo, pūslinès išvisos atvejais, vaisiaus žūties 24-ą nèštumo savaitę ir išnešioto néštumo atvejais. Devyniais atvejais EPV buvo matoma makroskopiškai: nuo $10 \mathrm{~mm}$ iki $45 \mathrm{~mm}$ mazgeliai, plokštelès, cistinès masès, polipoidiniai dariniai. Iš jų - penkiais atvejais kliniškai reiškèsi negausus pasikartojantis tepliojimas kraujingomis išskyromis arba trumpalaikiai gausūs kraujavimai, keturiais atvejais kraujavimo nebuvo. Likusiais dviem atvejais be makroskopinių pokyčių pasireiškè masyvus kraujavimas dèl gimdos atonijos po gimdymo, kurio nepavyko sustabdyti konservatyviomis priemonemis. Pažeidimai rezekuoti cezario pjūvio operacijos metu dviem atvejais, likusiais devyniais atvejais atlikta histerektomija tikslu išvengti progresuojančios gestacinès trofoblastinès ligos ar sustabdyti gausų, nekontroliuojamą kraujavimą iš gimdos. Nors EPV apibūdinama labiau kaip normalaus fiziologinio proceso kraštutinumas nei tikrasis pažeidimas ir dažniausiai diagnozuojama mikroskopiškai, daugumoje šių apžvelgtų atvejų buvo stebimas masès formavimasis [2].

EPV morfologinio vaizdo pagrindą sudaro vienbranduo- 
lių implantacijos vietos tarpinio trofoblasto ląstelių masyvi infiltracija endometriume ir miometriume. Šios ląstelès sudarytos iš gausios eozinofilinès citoplazmos su hiperchrominiu, netaisyklingu branduoliu [4]. Taip pat EPV randamas įvairus skaičius daugiabranduolių ląstelių. Nors infiltracija yra gausi, bendras architektūrinis vaizdas nesutrikdytas: endometriumo liaukos, spiralinès arterijos apsuptos ląstelių, tačiau nepažeistos, lygiai taip pat miometriumo skaidulas skiria tarpinio trofoblasto ląstelių sudarytos stygos, lizdai ar pavienès ląstelès, be nekrozès [4]. Paprastai randami ir kiti něštumui būdingi požymiai: hialinizuotos spiralinès arterijos, hipersekretuojančios liaukos, choriono gaureliai [2].

Kartais būna sunku, bet būtina EPV atskirti nuo kitos gestacinès trofoblastinès patologijos, kadangi skirtingi trofoblastiniai pažeidimai reikalauja skirtingo gydymo. EPV reikia diferencijuoti nuo placentos vietos mazgo (angl. placental site nodule), placentos vietos trofoblastinio naviko (PVTN, angl. placental site trophoblastic tumor), epitelioidinio trofoblastinio naviko (angl. epithelioid trophoblastic tumor), choriokarcinomos [1]. Tiksli diagnozė nustatoma pagal morfologinius bruožus ir fenotipavimą. Sunkiausia EPV diferencijuoti nuo placentos vietos trofoblastinio naviko, ypač abrazinejje medžiagoje, nes abiejų šių pažeidimų tarpinio trofoblasto ląstelès citologiškai ir imunofenotipiškai panašios [2]. EPV būdingi klinikiniai něštumo požymiai, be matomo darinio miometriume, tuo tarpu PVTN būdingas darinys miometriume, paprastai praejjus mėnesiams po gimdymo ar aborto. EPV tai paprastai mikroskopinis pažeidimas, stingantis mitotinio aktyvumo, sudarytas iš hialino masių atskirtų tarpinio trofoblasto ląstelių, su ịsimaišiusia decidua ir choriono gaureliais. Priešingai, pažeidimas, kuriame nerandama choriono gaurelių, sudarytas iš tarpinio trofoblasto ląstelių susiliejančių masių, su aiškiomis mitotinèmis figūromis priskiriamas placentos vietos trofoblastiniam navikui [3]. Daugiabranduolès ląstelès dažniau randamos EPV. Tais atvejais, kuomet yra ypač sunku atskirti šias dvi patologijas, ypač naudingas gali būti Ki-67 proliferacijos indeksas. Pastarujų metų tyrimai rodo, kad branduolio žymens Ki-67 indeksas, naudojant Ki-67 specifinius (MIB-1) antikūnius, yra reikšmingesnis už mitotinį indeksą diferencijuojant EPV ir placentos vietos trofoblastinį naviką. Specifiškai, Ki-67 indeksas EPV atveju yra artimas $0(<1$ proc.), tuo tarpu PVTN atveju šis indeksas yra apie 10 proc. (14 proc. $\pm 6,9$ proc.) [5].

EPV yra nepiktybinè patologija, išnykstanti po gimdos kiuretažo. Ji nesiejama su padidejusia persistuojančios gestacinès trofoblastinès ligos rizika. Joks specifinis gydymas bei tolimesnis moters stebejjimas nereikalingas. Tais atvejais, kuomet EPV negalima patikimai atskirti nuo placentos vietos trofoblastinio naviko, rekomenduojamas kartotinis žmogaus chorioninio gonadotropino (hCG) titrų sekimas [4].

\section{Išvados}

Eksagreguota placentos vieta, tai histologinè diagnozé, nustatoma, kai implantacijos vietos tarpinio trofoblasto ląstelès plačiai išplinta endometriume ir miometriume ir tai galimai yra normalios nèštumo fiziologijos kraštutinè forma. Dažniausiai klinikinių simptomų nebūna, EPV nustatoma retrospektyviai. Retai sukelia kraujavimą néštumo metu, gimdos atoniją ir gausų kraujavimą po gimdymo ar net pažeistos gimdos sienelès perforaciją. Minètais atvejais, nenustačius kitos kraujavimo priežasties, reiktų pagalvoti apie EPV. Nors tai gerybinis trofoblasto pažeidimas, apie ji būtina žinoti ir diferencijuoti nuo kitų gerybinių ir ypač paribinių ar piktybinių ligų, tokių kaip placentos vietos trofoblastinis navikas, epitelioidinis trofoblastinis navikas ir choriokarcinoma, kuriems reikalingi agresyvūs gydymo protokolai.

\section{Literatūra}

1. Shetty A, Narasimha A, Jyalakshmi VJ. Exaggerated placental site reaction: case report of a rare benign trophoblastic lesion. Int J Reprod Contracept Obstet Gynecol 2015;4(5):1647-1649.

2. Takebayashi A, Kimura F, Yamanaka A, Takahashi A, Tsuji S, Ono T. et al. Exaggerated placental site, consisting of implantation site intermediate trophoblasts, causes massive postpartum uterine hemorrhage: case report and literature review. Tohoku J. Exp. Med 2014; 234, 77-82.

3. Ozdemir O, Sari ME, Selimova V, Ilgin BU, Atalay CR. A case report of complete mole with co-existent exaggerated placental site reaction and review of the literature. Niger Med J 2014;55(2):180-2.

4. Kadian ND, Singh S, Rajotia N, Dahiya K, Jain S, Malik R. Exaggerated placental site: a cause of postpartum collapse? J South Asian Feder Obst Gynae 2015;7(3):148-151.

5. Shih IM, Kurman RJ. Ki-67 labeling index in the differential diagnosis of exaggerated placental site, placental site trophoblastic tumor, and choriocarcinoma: a double immunohistochemical staining technique using Ki-67 and MEL-CAM antibodies. Hum Pathol 1998;29(1):27-33.

6. Jayakrishnan N, Jayakrishnan K. A placental dilemma: exaggerated placental site tumour. Int J Reprod Contracept Obstet Gynecol 2016;5(7):2425-2427.

\section{EXAGGERATED PLACENTAL SITE: A CASE REPORT \\ D. Smetonienė, J. Volochovič}

Key words: exaggerated placental site, intermediate trophoblast, bleeding during pregnancy.

Summary

Exaggerated placental site is a rare non-neoplastic trophoblastic lesion in which extravilleous intermediate trophoblastic cells extensively infiltrate into the endometrium and the underlying myome- 


\section{0}

trium. Most often, it is a histological diagnosis made after examination of uterine curettage specimens obtained after first trimester spontaneous or induced abortions. Rarely, the lesion may present as continuous blood spotting or short term active uterine bleeding in pregnancy or postpartum hemorrhage. It is important to differentiate this lesion from other gestational pathology as different trophoblastic lesions require different therapeutic approaches.

In a case of exaggerated placental site, no specific treatment or follow-up is necessary. It is not associated with increased risk of persistent gestational trophoblastic disease. We present a rare case of an exaggerated placental site reaction in an $18^{\text {th }}$ week pregnant woman. The woman experienced recurrent life-threatening vaginal bleeding. A decision was made by multidisciplinary team not to continue pregnancy. During operation, morbidly adherent placenta was suspected, thus total abdominal hysterectomy without bilateral salpingo-oophorectomy was performed. The histology revealed exaggerated placental site.

Correspondence to: dovile@smetonis.com

Gauta 2017-10-30 